\title{
Modulation of Serotonin 2C Receptor Editing by Sustained Changes in Serotonergic Neurotransmission
}

\author{
Ilona Gurevich, ${ }^{1,2}$ Michael T. Englander, ${ }^{2}$ Mella Adlersberg, ${ }^{2}$ Nathan B. Siegal, ${ }^{2}$ and Claudia Schmauss ${ }^{1,2}$ \\ ${ }^{1}$ Department of Psychiatry and ${ }^{2}$ Division of Neuroscience, Columbia University College of Physicians and Surgeons, New \\ York, New York 10032
}

Serotonin $2 \mathrm{C}\left(5-\mathrm{HT}_{2 \mathrm{C}}\right)$ receptor pre-mRNA is a substrate for RNA editing enzymes that convert five adenosines (named $A, B$, $C^{\prime}, C$, and D editing sites) to inosines. Editing of two of these sites $\left(C^{\prime}\right.$ and $C$ ) is crucial for decreasing the efficiency of the receptor to activate G-protein. Nucleotide sequence analysis of mouse forebrain neocortical $5-\mathrm{HT}_{2 \mathrm{C}}$ mRNA isoforms revealed that editing at these two sites is regulated in a serotonindependent manner. In serotonin-depleted mice, $\mathrm{C}^{\prime}$ - and C-site editing is significantly decreased. This results in an increased expression of $5-\mathrm{HT}_{2 \mathrm{C}}$ mRNA isoforms encoding receptors with higher sensitivity to serotonin. In contrast, a $4 \mathrm{~d}$ treatment with the $5-\mathrm{HT}_{2 \mathrm{~A} / 2 \mathrm{C}}$ agonist $( \pm)$-1-(4-iodo-2,5-dimethoxyphenyl)-2-

The conversion of adenosine (A) to inosine (I) by ADARs (adenosine deaminases that act on RNA) is the most widespread editing in higher eukaryotes (Bass, 2002). Although the total inosine content of rat brain poly $\left(\mathrm{A}^{+}\right)$RNA predicts that one inosine occurs approximately once every 17,000 nucleotides (Paul and Bass, 1998), only a few neuronal substrates for A to I editing have been identified. They include the serotonin $2 \mathrm{C}\left(5-\mathrm{HT}_{2 \mathrm{C}}\right)$ receptor, the first G-protein-coupled receptor known to be edited. In $5-\mathrm{HT}_{2 \mathrm{C}}$ pre-mRNA, a total of five closely spaced adenosines (named A, B, C', C, and D editing sites) located within a sequence that encodes the second intracellular loop of the receptors protein can be converted to inosines (Burns et al., 1997; Niswender et al., 1999). This editing can change up to three triplet codons and has the potential to generate 24 different protein isoforms. Compared with nonedited $5-\mathrm{HT}_{2 \mathrm{C}}$ receptors, the receptor isoform that results from editing at the $\mathrm{ABCD}$ sites and other partially edited isoforms that are edited at the $\mathrm{C}^{\prime}$ site but not the $\mathrm{C}$ site exhibit a fourfold reduction in the efficiency to activate $\mathrm{G}$-protein in response to agonist stimulation. This reduction is even higher (15- to 25 -fold) for completely edited isoforms and other partially edited isoforms that are edited at both $\mathrm{C}^{\prime}$ and $\mathrm{C}$ sites. Other partially edited isoforms that are not edited at the $\mathrm{C}^{\prime}$ and/or C site appear to be fully functional (Niswender et al., 1999; Wang et al., 2000).

At present, the significance of $5-\mathrm{HT}_{2 \mathrm{C}}$ pre-mRNA editing in vivo is still unknown. However, a recent study indicates that this editing is regulated and suggests that this regulation is sensitive to

Received Aug. 15, 2002; revised Sept. 27, 2002; accepted Oct. 7, 2002.

This work was supported by National Institutes of Health Grant MH61906 (C.S.). We thank S. Glickstein for help with the drug treatments and tissue dissections.

Correspondence should be addressed to Claudia Schmauss, Department of Psychiatry/Neuroscience, Box 42, 1051 Riverside Drive, New York, NY 10032. E-mail: schmauss@neuron.cpmc.columbia.edu.

Copyright (C) 2002 Society for Neuroscience $0270-6474 / 02 / 2210529-04 \$ 15.00 / 0$ aminopropane significantly increases the editing frequency at the $\mathrm{C}^{\prime}$ site and leads to increased expression of $5-\mathrm{HT}_{2 \mathrm{C}}$ mRNA isoforms encoding receptors that activate G-protein least efficiently. None of the drug treatments led to alterations in cytoplasmic $5-\mathrm{HT}_{2 \mathrm{C}} \mathrm{mRNA}$ levels. These data indicate that editing of $5-\mathrm{HT}_{2 \mathrm{C}}$ pre-mRNA is a mechanism that retains basic response properties of $5-\mathrm{HT}_{2 \mathrm{C}}$ receptors in the face of changing synaptic input to keep receptor activation within an optimal range for information processing.

Key words: serotonin; 5-HT $2 C$ receptor; RNA editing; forebrain neocortex; 5-HT depletion; 5- $\mathrm{HT}_{2 \mathrm{~A} / 2 \mathrm{C}}$ agonist

changes in the synaptic concentration of 5-HT (Gurevich et al., 2002). Increased $C^{\prime}$ - and $C$-site editing and decreased D-site editing in prefrontal cortical $5-\mathrm{HT}_{2 \mathrm{C}}$ pre-mRNA of depressed suicide victims were found to result in a predominant expression of 5- $\mathrm{HT}_{2 \mathrm{C}}$ mRNA isoforms that code for a receptor population with compromised functional properties. In contrast, mice chronically treated with the serotonin-selective reuptake blocker fluoxetine (Prozac) exhibit decreased $\mathrm{C}^{\prime}$ - and $\mathrm{C}$-site editing and increased D-site editing and thus express forebrain neocortical $5-\mathrm{HT}_{2 \mathrm{C}}$ mRNA isoforms encoding a receptor population with higher sensitivity to 5-HT. These results raised the possibility that the changes in editing-site preferences detected in depressed suicide victims are attributable to lower synaptic 5-HT levels and that the opposite changes detected in fluoxetine-treated mice occurred in response to increased synaptic 5-HT. However, the actual synaptic concentration of 5-HT in the prefrontal cortex of depressed suicide victims is not known. Moreover, fluoxetine is also a competitive antagonist of $5-\mathrm{HT}_{2 \mathrm{C}}$ receptors ( $\mathrm{Ni}$ and Miledi, 1997), which could obscure the interpretation of the finding if signaling through $5-\mathrm{HT}_{2 \mathrm{C}}$ receptors is involved in regulating $5-\mathrm{HT}_{2 \mathrm{C}}$ pre-mRNA editing. Therefore, the present study sought to establish the precise nature of changes in editing-site preferences that occur in response to a sustained decrease in the concentration of synaptic 5-HT, as well as those that occur in response to a sustained activation of $5-\mathrm{HT}_{2 \mathrm{~A} / 2 \mathrm{C}}$ receptors. A comparison of forebrain neocortical editing-site preferences of normal mice with those of 5-HT-depleted and 5- $\mathrm{HT}_{2 \mathrm{~A} / 2 \mathrm{C}}$ agonisttreated mice revealed site-specific changes in editing that lead to increased expression of 5- $\mathrm{HT}_{2 \mathrm{C}}$ mRNA isoforms encoding fully functional receptors in 5-HT-depleted animals and decreased expression of these mRNA isoforms in agonist-treated animals. Thus, RNA editing adjusts the responses of postsynaptic $5-\mathrm{HT}_{2 \mathrm{C}}$ 
receptors to maintain their activity within an optimal range for information processing.

\section{MATERIALS AND METHODS}

Animals. Adult male 129Sv mice were housed in groups of four animals per cage. They were housed in a facility with a $12 \mathrm{hr}$ light/dark cycle and had access to food and water ad libitum. All procedures involving these animals were approved by the Institutional Animal Care and Use Committee at Columbia University.

Drug treatments. Para-chlorophenylalanine (pCPA) methyl ester and ( \pm )-1-(4-iodo-2,5-dimethoxyphenyl)-2-aminopropane (DOI) (Sigma, St. Louis, MO) were dissolved in saline and administered intraperitoneally. None of the drug treatments affected the general wellbeing of the animals. All animals showed normal locomotion and appeared to maintain normal sleeping during the daytime (observations made between 9:00 A.M. and 7:00 P.M.). The weight loss of pCPA-treated animals was $<5 \%$ of their normal body weight. At the end of the treatment, mice were killed by decapitation, and their brains were rapidly removed, dissected, and frozen at $-80^{\circ} \mathrm{C}$.

Tissue levels of 5-HT and nucleotide sequence analysis of 5- $\mathrm{HT}_{2 \mathrm{C}^{-}}$ encoded $c D N A$. The forebrain neocortex of one hemisphere and the hindbrain were used to determine the tissue levels of 5-HT and its metabolite 5-hydroxyindole-3-acetic acid (5-HIAA) levels by $\mathrm{C}_{18}$ reverse-phase HPLC and electrochemical detection as described previously (McGehee et al., 1997). The forebrain neocortex of the other hemisphere was used to extract RNA by means of guanidine-cesium chloride ultracentrifugation. 5- $\mathrm{HT}_{2 \mathrm{C}} \mathrm{cDNA}$ was generated by reverse transcription (RT)-PCR specified by primers that span the edited region and cloned into the plasmid vector pCRII (Invitrogen, Carlsbad, CA), and recombinant plasmids were introduced into bacteria as described previously (Gurevich et al., 2002). For each animal, a single bacterial transformation yielded $>250$ plasmid-containing colonies from which 60 were randomly selected to recover plasmid DNA for nucleotide sequencing using the dideoxy chain termination method. This yielded 51-60 5- $\mathrm{HT}_{2 \mathrm{C}}$ cDNA sequences for each animal.

Exponential RT-PCR and Southern blotting. For exponential RT-PCR experiments, equal amounts of oligo-dT-primed cDNA generated from $12 \mu \mathrm{g}$ of total RNA extracted from each of the 16 mice analyzed in this study were used as templates for PCR. Amplifications were terminated after $10,15,20$, and 25 cycles of amplification by removing an aliquot of the PCR reaction at each time point. Aliquots were loaded onto a $1 \%$ agarose gel and transferred to a membrane that was probed with a ${ }^{32} \mathrm{P}$-radiolabeled cDNA encoding a HindIII restriction fragment of the 5' portion of the open reading frame of the human $5-\mathrm{HT}_{2 \mathrm{C}} \mathrm{cDNA}$.

\section{RESULTS}

\section{5- $\mathrm{HT}_{2 \mathrm{c}}$ pre-mRNA editing in the forebrain neocortex of 5-HT-depleted mice}

Four adult male $129 \mathrm{~Sv}$ mice received a single injection of pCPA $(300 \mathrm{mg} / \mathrm{kg})$, a potent and irreversible inhibitor of tryptophane hydroxylase. Five days later, their tissue content of 5-HT and 5-HIAA was determined by HPLC. In both forebrain neocortex and hindbrain, 5-HT/5-HIAA levels were reduced by only $\sim 20 \%$ (Fig. 1). In these mice, the forebrain neocortical $5-\mathrm{HT}_{2 \mathrm{C}}$ premRNA editing pattern is highly similar to that described previously for nontreated mice (Gurevich et al., 2002), as illustrated for comparison in Figure 2. In both groups of mice, the major $5-\mathrm{HT}_{2 \mathrm{C}}$ mRNA isoforms result from editing of the ABD and $\mathrm{ABCD}$ sites, and they represent 43 and $\sim 15 \%$, respectively, of all sequences. Fully edited and partially edited mRNA isoforms containing inosines at the $\mathrm{C}^{\prime}$ site either alone or in combination with the $\mathrm{C}$ site represent only 10 and $5 \%$ of all sequences obtained from nontreated mice and modestly 5-HT-depleted mice, respectively (Fig. 2, top). Moreover, no significant differences were found in the percentages of editing at all five sites (Fig. 2, bottom).

Four additional mice received $300 \mathrm{mg} / \mathrm{kg}$ pCPA twice per day for a period of $5 \mathrm{~d}$. This treatment resulted in $\sim 80 \%$ reduction of 5-HT/5-HIAA levels in both forebrain neocortex and hindbrain

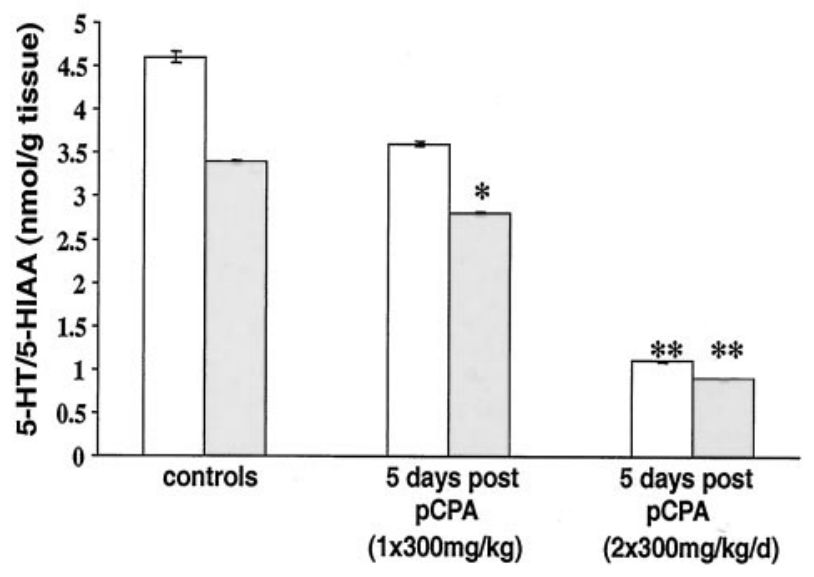

Figure 1. Tissue levels of 5-HT/5-HIAA in the forebrain neocortex $(C T X)$ and hindbrain of pCPA-treated mice. pCPA treatment regimens are indicated on the abscissa. Tissues levels of 5-HT and 5-HIAA levels were determined by $\mathrm{C}_{18}$ reverse-phase HPLC and are expressed as nanomoles per gram of tissue. Data represent the means \pm SEM of measurements obtained from four animals per treatment group. A Student's $t$ test was used to test for the significance of differences between groups. ${ }^{*} p<$ $0.05 ; * * p 0.001$.

tissues (Fig. 1). This reduction resulted in significant alterations in $5-\mathrm{HT}_{2 \mathrm{C}}$ pre-mRNA editing. Whereas the percentage of ABCD-sites-edited isoform is unaltered in these animals, the expression of the isoform resulting from editing at the ABD sites is significantly increased (ANOVA; $p<0.05$ ), and the expression of the fully edited mRNA and those partially edited mRNA isoforms containing inosines at the $\mathrm{C}^{\prime}$ site and $\mathrm{C}^{\prime} \mathrm{C}$ sites is significantly decreased $(p<0.05)$ (Fig. 2, top). These changes are also reflected in significantly lower percentages of editing at the $\mathrm{C}^{\prime}$ $(p<0.04)$ and $\mathrm{C}$ site $(p<0.02)$ (Fig. 2, bottom). Thus, a reduction in the synaptic concentration of 5-HT increases the expression of 5- $\mathrm{HT}_{2 \mathrm{C}}$ mRNA isoforms encoding receptors with diminished $\mathrm{C}^{\prime} \mathrm{C}$-sites editing and higher sensitivity to agonist stimulation. Recent data revealed that a $4 \mathrm{~d}$ (rather than a $5 \mathrm{~d}$ ) treatment with pCPA (two times at $300 \mathrm{mg} \cdot \mathrm{kg}^{-1} \cdot \mathrm{d}^{-1}$ ) is sufficient to induce the changes described above (data not shown).

\section{$5-\mathrm{HT}_{2 \mathrm{C}}$ pre-mRNA editing in DOI-treated mice}

To test whether prolonged stimulation of $5-\mathrm{HT}_{2 \mathrm{~A} / 2 \mathrm{C}}$ receptors would alter editing-site preferences in $5-\mathrm{HT}_{2 \mathrm{C}}$ pre-mRNA in a manner opposite from those detected in the 5-HT-depleted animals, four additional mice were treated with the $5-\mathrm{HT}_{2 \mathrm{~A} / 2 \mathrm{C}^{-}}$ selective partial agonist DOI (two times at $2 \mathrm{mg} \cdot \mathrm{kg}^{-1} \cdot \mathrm{d}^{-1}$ ) for $4 \mathrm{~d}$. This treatment also altered $5-\mathrm{HT}_{2 \mathrm{C}}$ pre-mRNA editing and resulted in a significantly reduced expression of the ABCD-sitesedited mRNA isoform $(p<0.01)$ together with a significantly increased expression of fully edited and partially edited mRNA isoforms that contain inosines at the $\mathrm{C}^{\prime}$ site and the $\mathrm{C}^{\prime} \mathrm{C}$ sites $(p<0.01)$ (Fig. 2, top). This change in the relative expression of $5-\mathrm{HT}_{2 \mathrm{C}}$ mRNA isoforms is mainly attributable to a significantly increased editing frequency at the $\mathrm{C}^{\prime}$ site $(p<0.04)$ (Fig. 2, bottom) and results in an increased expression of 5- $\mathrm{HT}_{2 \mathrm{C}} \mathrm{mRNA}$ isoforms encoding receptors that least efficiently activate G-protein. 

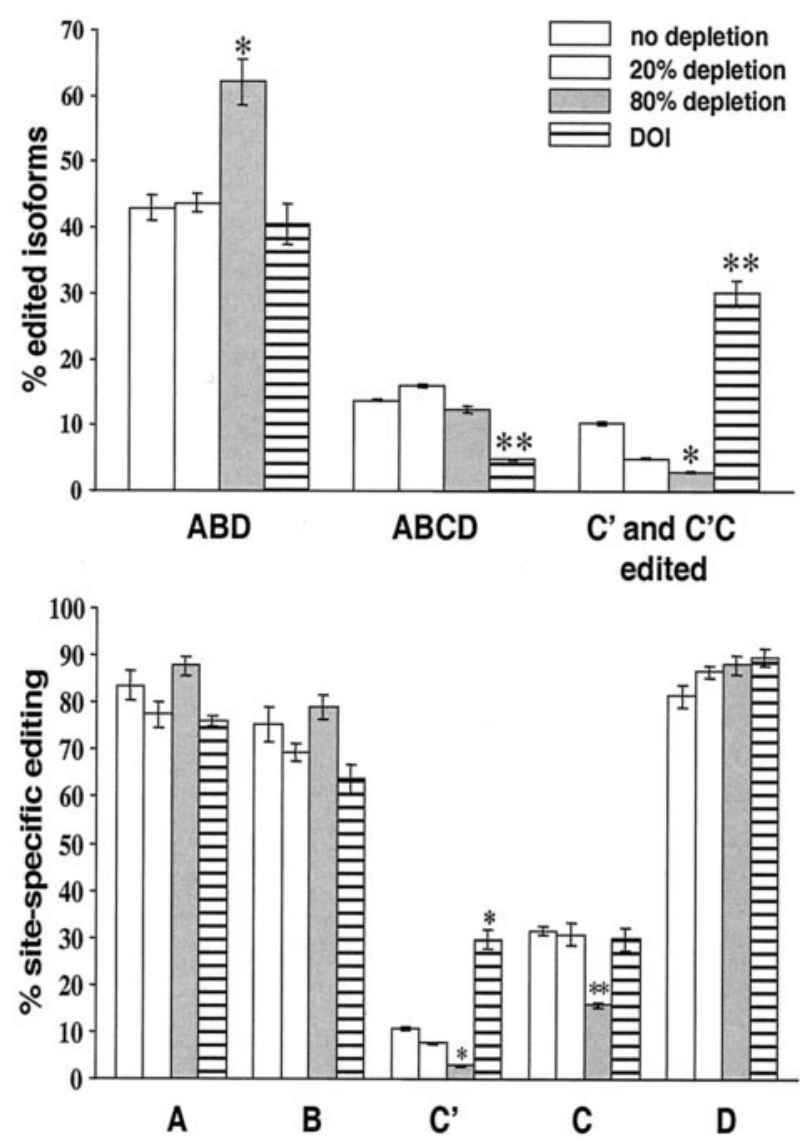

Figure 2. Expression of 5- $\mathrm{HT}_{2 \mathrm{C}}$ mRNA isoforms in the forebrain neocortex of drug-naive mice and mice treated with either pCPA or DOI. Comparison of the percentages of the major edited isoforms (top) and percentages of editing at the five editing sites (bottom). The data represent the means \pm SEM of percentages determined for controls $(n=4 ; 212$ sequences), pCPA-treated animals $(n=4$ for each of the two treatment regimens; 218 and 240 sequences), and DOI-treated animals ( $n=4 ; 228$ sequences). Data were compared by a one-way ANOVA, followed by Tukey-Kramer multiple comparisons test. Top, ${ }^{*} p<0.05 ; * * p<0.01$. Bottom, ${ }^{*} p<0.04 ;{ }^{* *} p<0.02$. Partially edited transcripts involving the $\mathrm{C}^{\prime}$ site are mRNA isoforms resulting from the editing combinations $A B C^{\prime} D$, $A C^{\prime} \mathrm{D}, \mathrm{C}^{\prime} \mathrm{D}$, and $\mathrm{C}^{\prime}$. Transcripts edited at both $\mathrm{C}^{\prime}$ and $\mathrm{C}$ sites included mRNA isoforms resulting from the editing combinations $\mathrm{ABC}^{\prime} \mathrm{CD}$, $\mathrm{AC}^{\prime} \mathrm{CD}, \mathrm{AC}^{\prime} \mathrm{C}, \mathrm{ABC} C^{\prime} \mathrm{C}, \mathrm{C}^{\prime} \mathrm{CD}$, and $\mathrm{C}^{\prime} \mathrm{C}$. The latter two were found only in DOI-treated animals.

\section{Cytoplasmic 5- $\mathrm{HT}_{2 \mathrm{C}}$ mRNA levels}

Because conventional measurements of cortical 5- $\mathrm{HT}_{2 \mathrm{C}}$ mRNA levels (Northern blotting or RNase protection assays) do not allow to reliably detect the very low abundant mRNA, we performed exponential RT-PCR experiments to compare with Southern blots the lowest number of PCR cycles needed to detect $5-\mathrm{HT}_{2 \mathrm{C}}$ amplification products. As shown in Figure 3,10 pg of plasmid DNA encoding the $5-\mathrm{HT}_{2 \mathrm{C}}$ receptor led to detectable $5-\mathrm{HT}_{2 \mathrm{C}}$ amplification products after 15 cycles of amplification. PCR templates of all 16 mice analyzed here required 15 cycles of PCR to yield clearly detectable amounts of 5- $\mathrm{HT}_{2 \mathrm{C}} \mathrm{cDNA}$. Moreover, in all of these samples, the PCR reaction was saturated after 25 cycles. Two representative examples for each treatment group are shown in Figure 3. The results indicate that none of the drug treatments that result in changes in $5-\mathrm{HT}_{2 \mathrm{C}}$ pre-mRNA editing altered the cytoplasmic expression levels of 5-HT $2 \mathrm{C}$ mRNA.
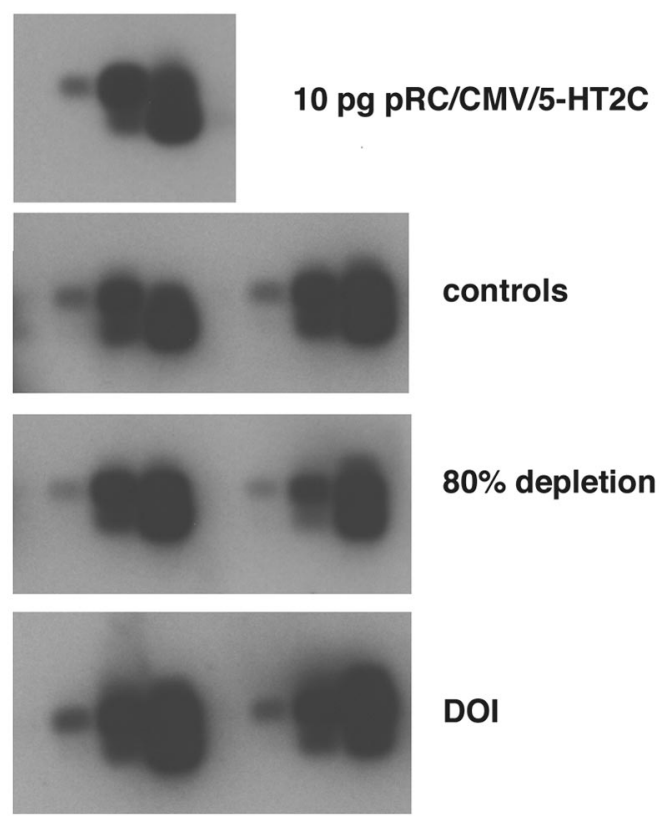

PCR cycles 1015202510152025

Figure 3. Expression levels of 5- $\mathrm{HT}_{2 \mathrm{C}} \mathrm{mRNA}$ in the forebrain neocortex of drug-naive mice and pCPA- and DOI-treated mice. Southern blot of exponential RT-PCR amplification of cDNA encoding a 270-nucleotidelong sequence of $5-\mathrm{HT}_{2 \mathrm{C}}$ mRNA sequence containing the edited region. Aliquots of the PCR reactions were removed after 10, 15, 20, and 25 cycles of amplification. For each treatment group, representative results obtained from two mice are shown, and, for comparison, PCR amplification of $0.01 \mathrm{ng}$ of plasmid DNA encoding the full-length $5-\mathrm{HT}_{2 \mathrm{C}}$ receptor is shown on top. Blots were exposed to film for $3 \mathrm{hr}$. CMV, Cytomegalovirus; $p R C$, plasmid vector RC (Invitrogen).

\section{DISCUSSION}

The results of the present study show that pharmacological manipulations that either decrease the concentration of synaptic serotonin or increase the activation of postsynaptic $5-\mathrm{HT}_{2 \mathrm{~A} / 2 \mathrm{C}}$ receptors for at least $4 \mathrm{~d}$ result in changes of $5-\mathrm{HT}_{2 \mathrm{C}}$ pre-mRNA editing-site preferences. Whereas reduced synaptic concentration of 5-HT induces a decrease in $\mathrm{C}^{\prime}$ - and $\mathrm{C}$-site editing, treatment with the partial agonist DOI increases the editing frequency at the $\mathrm{C}^{\prime}$ site. (Whether more potent full agonists would, in addition to increased $\mathrm{C}^{\prime}$-site editing, also lead to increased $\mathrm{C}$-site editing remains to be determined.) As a result, 5-HT-depleted animals exhibit increased expression of $5-\mathrm{HT}_{2 \mathrm{C}} \mathrm{mRNA}$-encoding receptor isoforms with higher sensitivity to serotonin, and DOI-treated animals express more mRNA isoforms that encode receptors that are less responsive to serotonin. Neither treatment altered the cytoplasmic expression levels of $5-\mathrm{HT}_{2 \mathrm{C}}$ mRNA. These data indicate that $5-\mathrm{HT}_{2 \mathrm{C}}$ pre-mRNA editing is a mechanism that retains basic response properties of $5-\mathrm{HT}_{2 \mathrm{C}}$ receptors in the face of sustained changes of synaptic input to keep receptor activation within an optimal range.

It should be emphasized that the changes in editing-site preferences described previously for mice treated chronically with fluoxetine (Gurevich et al., 2002) are similar to those detected in 5 -HT-depleted animals. This suggests that the changes in $5-\mathrm{HT}_{2 \mathrm{C}}$ pre-mRNA editing that resulted from fluoxetine treatment are not occurring in response to increased synaptic 5-HT (resulting from 5-HT reuptake inhibition by the drug). Our finding that selective stimulation of $5-\mathrm{HT}_{2 \mathrm{~A} / 2 \mathrm{C}}$ receptor alone alters $5-\mathrm{HT}_{2 \mathrm{C}}$ 
pre-mRNA editing suggests the possibility that the changes in $5-\mathrm{HT}_{2 \mathrm{C}}$ pre-mRNA editing detected in fluoxetine-treated mice are attributable to the blockade of $5-\mathrm{HT}_{2 \mathrm{C}}$ receptor activation by this drug (Ni and Miledi, 1997). However, more studies on mice treated with $5-\mathrm{HT}_{2 \mathrm{~A} / 2 \mathrm{C}}$-selective antagonist as well as different serotonin-selective reuptake inhibitors are needed to clarify this issue.

It is also of interest to note that the changes in editing-site preferences detected in depressed suicide victims (Gurevich et al., 2002) are opposite from those detected in 5-HT-depleted animals. It is generally believed that depression associates with decreased serotonin levels, and, in the prefrontal cortex, the expression of serotonin transporter radioligand-binding sites has been found to be decreased by $\sim 20-30 \%$ (Mann et al., 2000). If this decreased 5-HT transporter expression reflects the extent of decreased serotonergic innervation of the prefrontal cortex, our data obtained from mice with a $20 \%$ depletion of 5-HT suggest that the magnitude of this decrease is unlikely to affect $5-\mathrm{HT}_{2 \mathrm{C}}$ pre-mRNA editing. Moreover, the most significant change in editing-site preference detected in depressed suicide victims (increased $\mathrm{C}^{\prime}$-site editing) could be reproduced in the forebrain neocortex of mice treated with DOI. This finding raises the possibility that the changes in editing-site preferences detected in depressed suicide victims are attributable to increased stimulation of prefrontal cortical $5-\mathrm{HT}_{2 \mathrm{~A} / 2 \mathrm{C}}$ receptors. Alternatively (and perhaps more likely), the normal regulation of $5-\mathrm{HT}_{2 \mathrm{C}}$ premRNA editing could be malfunctioning in these brains, a scenario that would contribute to a defective information processing of serotonergic neurotransmission.
In any case, elucidating the molecular mechanisms underlying the site-specific modulation of $5-\mathrm{HT}_{2 \mathrm{C}}$ pre-mRNA editing will be a challenging future task. Such mechanisms are likely to be very complex and could involve distinct alterations in the secondary structure of the pre-mRNA, receptor-mediated activation of distinct signaling molecules, and/or alterations in editing enzyme activities.

\section{REFERENCES}

Bass BL (2002) RNA editing by adenosine deaminases that act on RNA. Annu Rev Biochem 71:817-846.

Burns C, Chu H, Rueter S, Hutchinson LK, Canton H, Sanders-Bush E, Emeson RB (1997) Regulation of serotonin-2C receptor G-protein coupling by RNA editing. Nature 387:303-308.

Gurevich I, Tamir H, Arango V, Dwork A, Mann JJ, Schmauss C (2002) Altered editing of serotonin $2 \mathrm{C}$ receptor pre-mRNA in the prefrontal cortex of depressed suicide victims. Neuron 43:349-356.

Mann JJ, Huang Y-Y, Underwood MD, Kassir SA, Oppenheim S, Kelly TM, Dwork AJ, Arango V (2000) A serotonin transporter gene promotor polymorphism (5-HTTLPR) and prefrontal cortical binding in major depression and suicide. Arch Gen Psychiatry 57:729-738.

McGehee DS, Adlersberg M, Liu K-P, Hsiung S-C, Heath MJS, Tamir H (1997) Mechanism of extracellular $\mathrm{Ca}^{2+}$-receptor-stimulated hormone release from sheep thyroid parafollicular cells. J Physiol (Lond) $502: 31-44$

$\mathrm{Ni}$ YG, Miledi R (1997) Blockade of $5-\mathrm{HT}_{2 \mathrm{C}}$ serotonin receptors by fluoxetine (Prozac). Proc Natl Acad Sci USA 94:2036-2040.

Niswender C, Copeland SC, Herrik-Davis K, Emeson RB, Sanders-Bush E (1999) RNA editing of the human serotonin 5-hydroxytryptamine 2C receptor silences constitutive activity. J Biol Chem 274:9472-9478.

Paul MS, Bass BL (1998) Inosine exists in mRNA at tissue-specific levels and is most abundant in brain mRNA. EMBO J 17:1120-1127.

Wang Q, O'Brien P, Chen C-X, Cho D-SC, Murray JM, Nishikura K (2000) Altered G protein-coupling functions of RNA editing isoform and splicing variant serotonin 2 C receptors. J Neurochem 74:12901300 . 